(C) The Author(s), 2021. Published by Cambridge University Press for the Arizona Board of Regents on behalf of the University of Arizona. This is an Open Access article, distributed under the terms of the Creative Commons Attribution licence (http://creativecommons.org/licenses/by/4.0/), which permits unrestricted re-use, distribution, and reproduction in any medium, provided the original work is properly cited.

\title{
NEW MARINE RESERVOIR CORRECTION VALUES ( $\triangle R$ ) APPLICABLE TO DATES ON NEOLITHIC SHELLS FROM THE SOUTH COAST OF KOREA
}

\author{
Habeom Kim(i) - Hyunsoo Lee(1) - Gyoung-Ah Lee*(i) \\ Department of Anthropology, University of Oregon, 1321 Kincaid Street, Eugene, OR 97405, USA
}

\begin{abstract}
Shells from Neolithic shell midden sites have been routinely dated in Korea, but they have not been calibrated based on the correction values $(\Delta R)$ for the marine reservoir effect (MRE). A lack of proper calibration has left dates on shells incomparable to those on terrestrial samples, and thus unusable in building the chronological sequence of shell middens. Here, we report the two new $\Delta \mathrm{R}$ values of a pre-bomb (pre-1950) blue mussel from the south coast. We applied the two new and the two previously reported $\Delta \mathrm{R}$ values to the three dates on marine shells from the Bibongri shell midden in southeastern Korea. Our $\Delta \mathrm{R}$ adjusted calibration and the comparison to dates on charcoal and bone remains clarify an ambiguity in the stratigraphy and the Early Neolithic chronology at Bibongri. Our contribution is to provide the $\Delta \mathrm{R}$ values that can be further applied to other Neolithic shell middens along the south coast.
\end{abstract}

KEYWORDS: Korea, marine reservoir effect, Neolithic shell midden, $\Delta \mathrm{R}$.

\section{INTRODUCTION}

Radiocarbon $\left({ }^{14} \mathrm{C}\right)$ datasets have been used in archaeology not only to build regional chronologies but also to study population dynamics, settlement changes, and the correlations between changes in environments and culture (e.g., Anderson et al. 2011; Crema et al. 2016). A large number of ${ }^{14} \mathrm{C}$ dates are readily available in site reports, leading to an increase of radiocarbon studies in Korean archaeology since the 2010s. Popular topics include subsistence changes (Bae et al. 2013), temporal variabilities of hunter-gatherer sedentism (Ahn et al. 2015), settlement changes during state formations (Park et al. 2017), and population dynamics (Oh et al. 2017).

In Korea, a considerable number of shell dates is associated with the shell middens dating to the Neolithic period (ca. 8000-3500 cal BP). Over 600 shell middens have been documented in Korea, a large percentage (46\%) belonging to the Neolithic period (Ha 2010), and some of well-stratified shell middens have provided key data on establishing the regional chronology. Although marine shells from these Neolithic shell middens are frequently dated materials, counting 120 or more, their ${ }^{14} \mathrm{C}$ dates are often underutilized or used without proper calibration accounting for the marine reservoir effect (MRE). The MRE contributes to the disparity between the ${ }^{14} \mathrm{C}$ ages obtained from terrestrial and marine samples. Several factors contribute to this gap, especially upwelling, which occurs when an "older" carbon upwells from the deep ocean and is taken in by marine organisms (Soares and Martins 2010). Recently, Heaton et al. (2020) presented Marine20, an update to the internationally agreed marine radiocarbon age calibration curve. Marine20 models the global influence of the MRE by simulating the ocean/atmosphere/biosphere box-model of the global carbon cycle while also integrating the ice core data on the observed changes in $\mathrm{CO}_{2}$. The regional MRE, however, can deviate from the global model due to the variations in the fluvial influx and ocean upwelling (Smittenberg et al. 2004; Cook et al. 2015). By offsetting these

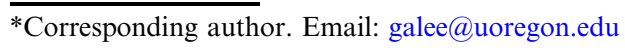


impacts, the regional correction value $(\Delta R)$ can adjust the global pattern of the MRE and thus be used to calibrate the radiocarbon age of marine organisms correctly.

Utilizing marine shell dates in Korea has been difficult in part due to the lack of $\Delta \mathrm{R}$ values. Although several values are available from the surrounding regions (Kuzmin et al. 2001; Southon et al. 2002; Shishikura et al. 2007; Yoneda et al. 2007; Hirabayashi et al. 2017), only two $\Delta \mathrm{R}$ values are available in Korea (Kong and Lee 2005) (Table 1). The provenience of shells used in Kong and Lee's (2005) study, however, is only known as the south coast without further details. As $\Delta \mathrm{R}$ values can be highly variable in coastal regions (Kuzmin et al. 2001; Butler et al. 2009; Thornalley et al. 2011; Napolitano et al. 2019), previously published values from surrounding regions may not be applicable to the Korean Peninsula. Without additional applicable $\Delta \mathrm{R}$ values, marine shell dates have a limited value contributing to the Neolithic chronology. Therefore, the chronology is often built exclusively upon pottery typology and ${ }^{14} \mathrm{C}$ dates on charcoal. The Bibongri shell midden site $\left(35^{\circ} 24^{\prime} 38^{\prime \prime} \mathrm{N}, 128^{\circ} 38^{\prime} 44^{\prime \prime} \mathrm{E}\right)$ is one of such cases in southeastern Korea (Figure 1). As a multi-component site (7800-2800 cal BP), Bibongri provides a wealth of information on subsistence and material culture throughout the Neolithic periods with well-preserved organic remains (Supplementary Material 1) (Gimhae National Museum 2008, 2012). By adding $\Delta \mathrm{R}$ values and ${ }^{14} \mathrm{C}$ dates, several studies in eastern Eurasia reassessed the regional settlement patterns and the time depth of the sites, including the Neolithic Boisman 2 site in Primorye (Jull et al. 1994; Kuzmin et al. 1994, 2002).

Our study reports two new $\Delta \mathrm{R}$ values. We calculate the weighted mean based on these new $\Delta \mathrm{R}$ values and those published in Kong and Lee (2005) and apply to the calibration of archaeological shells from Bibiongri. Among several cultural layers identified at Bibongri, Shell Layer 1 is the thickest strata, revealing abundant artifacts and organic remains. By comparing the calibrated marine shell dates to those on charcoal and bone fragments from Shell Layer 1, we aim to address the time depth of this cultural layer.

\section{METHODS}

\section{Specimen Used}

We obtained one pre-bomb blue mussel (Mytilus edulis) specimen, live-collected at the Busan Bay of South Gyeongnam Province, South Korea on May 29, 1938 (Table 2; Figure 1). The bivalve specimen was preserved in an $80 \%$ aqueous solution of ethanol in an air-tight container at the Fisheries Science Museum located in Busan, South Korea.

Blue mussels inhabit rocky, low, intertidal shores, sheltered harbors, open coasts with hard substrates, or any place with dense masses suitable for their body attachment (Al-Dabbas et al. 1984; Hong 2006; Lee et al. 2006). This marine mollusk is widely used for measuring local pollution levels because of its immobile living habit that results in an exclusive intake of nutrients from the local seawater. Its lifespan varies from three to 24 years, depending on the habitat environment (Seed 1969; Thiesen 1973). Most specimens curated at the Fisheries Science Museum between 1905 to 1943 were collected from the harbor of Busan, including the blue mussel specimen used in this study. 
Table $1 \Delta \mathrm{R}$ values within $823 \mathrm{~km}$ proximity to the study area, calibrated based on Marine 20 .

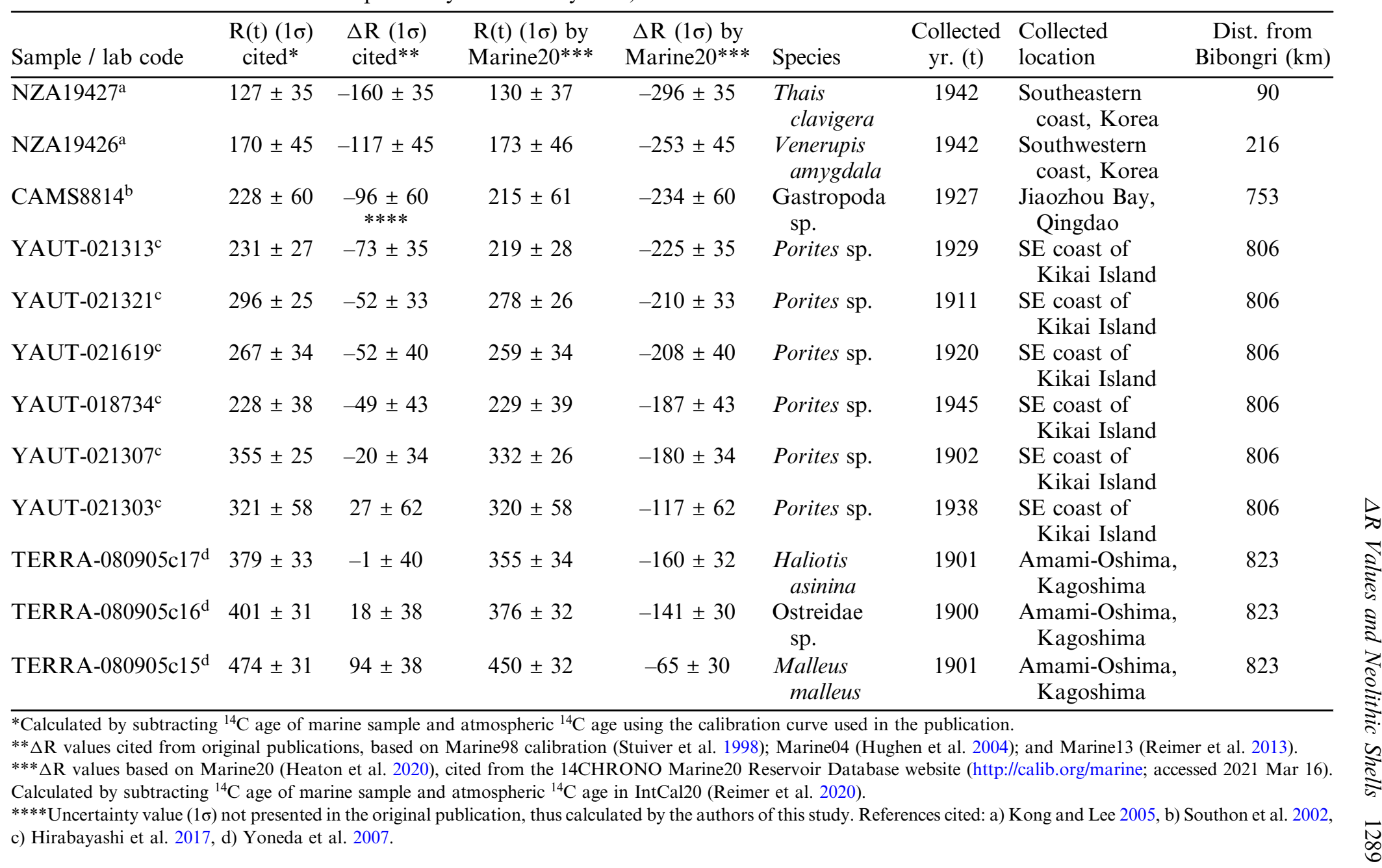




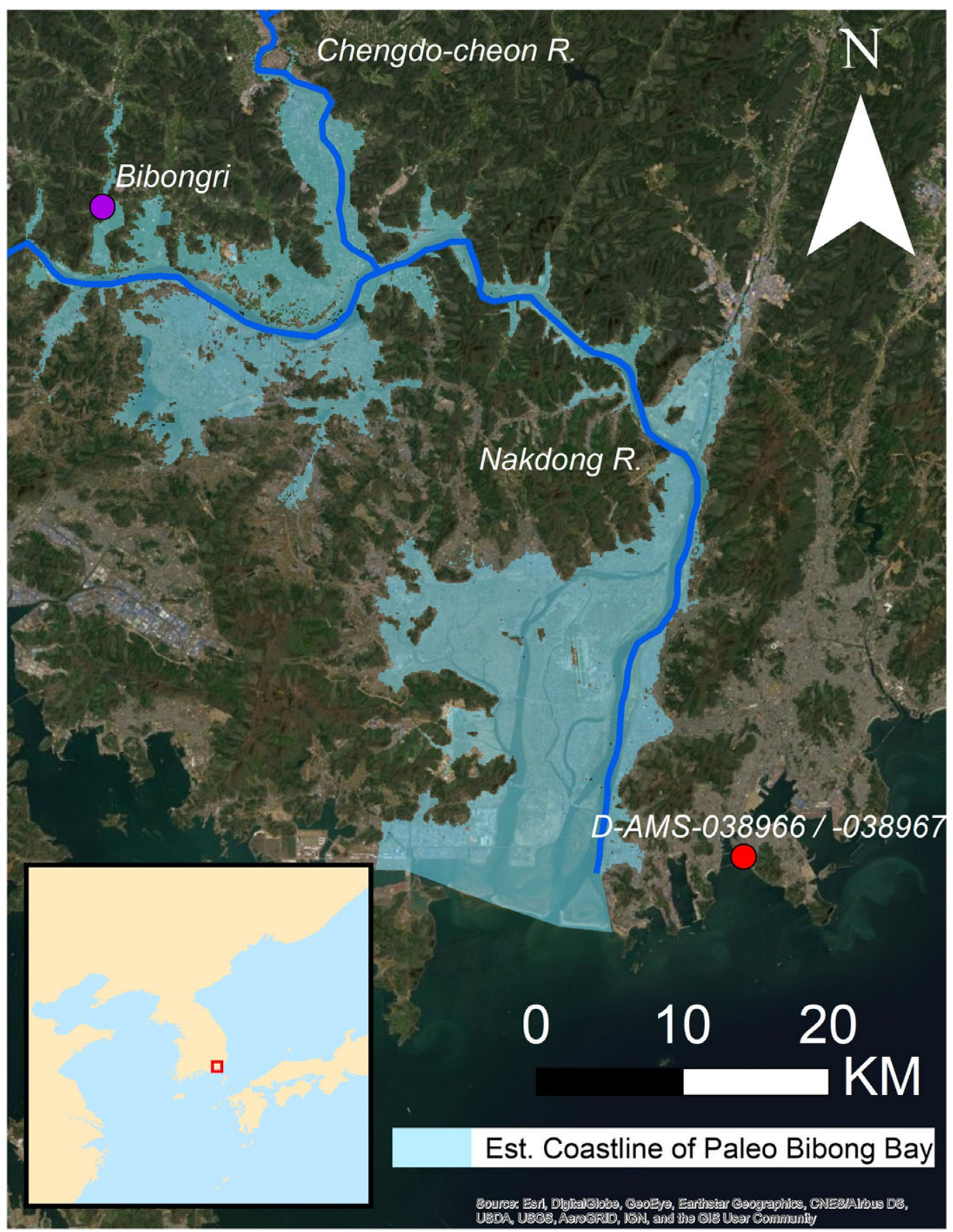

Figure 1 The provenience of pre-bomb shell sample and Bibongri archaeological site, and the estimated coastline of Paleo Bibong Bay, which is in a lighter shade than the river channel (modeled after the Gimhae National Museum 2012: 4). 
Table 2 Two ${ }^{14} \mathrm{C}$ dates from a pre-bomb shell specimen and their $\Delta \mathrm{R}$ values.

\begin{tabular}{lcc}
\hline AMS lab code & D-AMS-038966 & D-AMS-038967 \\
\hline${ }^{14} \mathrm{C}$ yr BP (conventional age) & $510 \pm 22$ & $533 \pm 24$ \\
Percent modern carbon (pMC, $1 \sigma)$ & $93.85 \pm 0.26$ & $93.58 \pm 0.28$ \\
$\delta^{13} \mathrm{C}(\% 0, \mathrm{~V} P \mathrm{~B})^{*}$ & -0.24 & -0.24 \\
$\mathrm{R}(\mathrm{t})(1 \sigma)^{* *}$ & $347 \pm 25$ & $370 \pm 26$ \\
$\Delta \mathrm{R}(1 \sigma)$ & $-93 \pm 22$ & $-70 \pm 24$ \\
Weighted mean $\Delta \mathrm{R}(1 \sigma)$ & $-83 \pm 16$ \\
Family & \multicolumn{2}{c}{ Mytilidae } \\
Scientific name & Mytilus edulis (Linnaeus 1758) \\
Common name & Blue mussel; Jinjudamchi (Korean); \\
Specimen registry no. & Murasakiigai (Japanese) \\
Collection date & NFRDI-MS-IS-0000078 \\
Collection location & \multicolumn{2}{c}{ May 29, 1938 } \\
\hline
\end{tabular}

*The $\delta^{13} \mathrm{C}$ values in this table were calculated using isotope ratio mass spectrometry (IRMS) at the Stable Isotope Laboratory, University of Oregon.

${ }^{* *}$ Calculated by subtracting ${ }^{14} \mathrm{C}$ age of marine sample and atmospheric ${ }^{14} \mathrm{C}$ age in IntCal20 (Reimer et al. 2020).

\section{Shell Preparation}

We cleansed the specimen through soaking and gently brushing with deionized water. The exterior organic layers (periostracum) were etched using 10\% hydrochloric acid solution and air-dried for $36 \mathrm{hr}$ to remove foreign substances and diagenetically altered carbonate. The shell was microscopically inspected for an intact terminal edge. Axial locations of the terminal growth margin were carefully sampled by hand with $0.05 \mathrm{~mm}$ carbide tip and drill bit at the University of Oregon Island and Coastal Archaeology Laboratory (Figure 2).

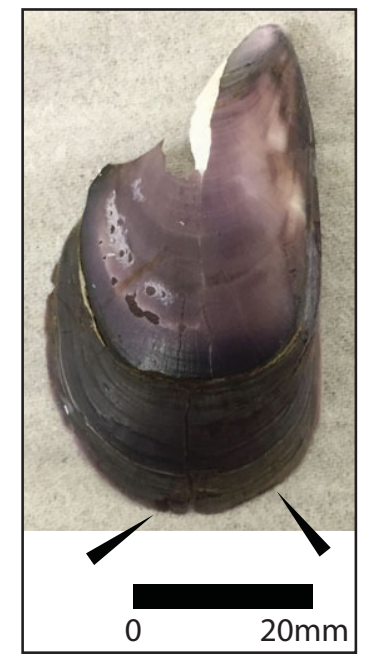

Figure 2 Pre-bomb shell specimen (Mytilus edulis, D-AMS-038966 and -038967) used in this study. Arrows show spots sampled for analysis. 
Two sets of particles were sampled from the same specimen (NFRDI-MS-IS-0000078), constituting the two AMS submissions (D-AMS-038966 and D-AMS-038967) (Table 2). The radiocarbon date measurement was processed with the NEC Pelletron $500 \mathrm{kV}$ AMS device at the DirectAMS (D-AMS) facility (see Zoppi 2010).

\section{Calculation of $\Delta R$ and the Weighted Mean $\Delta R$}

We followed the standard procedure of calculating $\Delta \mathrm{R}$, used by Kong and Lee (2005) and other studies (Phelan 1999; Yoshida et al. 2010; Nakanishi et al. 2017; Panich et al. 2018). First, we selected a marine shell specimen from the pre-bomb (pre-1950) era to avoid the "bomb effect," which increased the global atmospheric ${ }^{14} \mathrm{C}$ levels (Nydal 1968; Levin et al. 1985).

$$
\begin{gathered}
R_{\text {global }}(t)=14 C A g e_{\text {ocean }}-14 C \text { Age } e_{\text {atmosphere }} \\
R_{\text {marine sample }}(t)=14 C \text { Age }_{\text {marine sample }}-14 C \text { Age } e_{\text {atmosphere }} \\
R_{\text {marine sample }}(t)=R_{\text {global }}(t)+\Delta R \\
\Delta R=R_{\text {marine sample }}(t)-R_{\text {global }}(t)
\end{gathered}
$$

where

$R=$ Reservoir Age; $t=$ calendar year

Equations (1)-(4) discuss the method of deriving $\Delta \mathrm{R}$ (Jull et al. 2013). $\Delta \mathrm{R}$ is the difference between the reservoir age of marine sample and that of the global ocean age model, the Marine20 calibration curve in this study (Heaton et al. 2020). We used the Calib website (QUB 2021a) for the calculation of $\Delta R$. Then we calculated a weighted mean to combine multiple $\Delta$ Rs into a single value while placing a more weight on the value with a lower error range. The weighted mean is derived by using the equation on the Calib website (see Bevington 1969, QUB 2021b). We apply the weighted mean $\Delta \mathrm{R}$ to the archaeological shell samples from the Bibongri Site for the ${ }^{14} \mathrm{C}$ age calibration. The calibration was made with OxCal 4.3.2 (Bronk Ramsey 2009, 2017; Bronk Ramsey and Lee 2013), based on IntCal20 atmospheric curve and Marine20 marine curve (Heaton et al. 2020; Reimer et al. 2020).

\section{Bibongri Site}

Bounded by steep hills (400 m asl) to the north and west, Bibongri is located at the bottom of the foothills, overlooking an alluvial plain $(3.8 \mathrm{~m}$ asl) along the Chengdo-cheon river, a tributary of the Nakdong River (Figure 3). Although Bibongri is located inland today, it sat on a widened bay called Paleo Bibong throughout the Neolithic period and thus Neolithic inhabitants faced an inner bay environment (Gimhae National Museum 2008; Williams et al. 2013). Bibongri's coastal landscape is well documented by several studies. Sea-level and sedimentological studies exhibit that human activities at Neolithic Bibongri were largely affected by seawater dynamics (Hwang 2008, 2012; Hwang et al. 2013). Over $90 \%$ of diatoms identified from Shell Layer 1 belong to marine species, including Coscinodiscus sp., Nitzschia cocconieformis, and Nitzschia granulata (Hwang 2008, 2012). Marine shell species, including pacific oyster (Magallana gigas) and blood cockle (Tegillarca granosa), are also abundant in Shell Layer 1 (Gimhae National Museum 2008; Kaneko 2008). After the site was abandoned, Bibongri transformed into a low-lying 
(a)

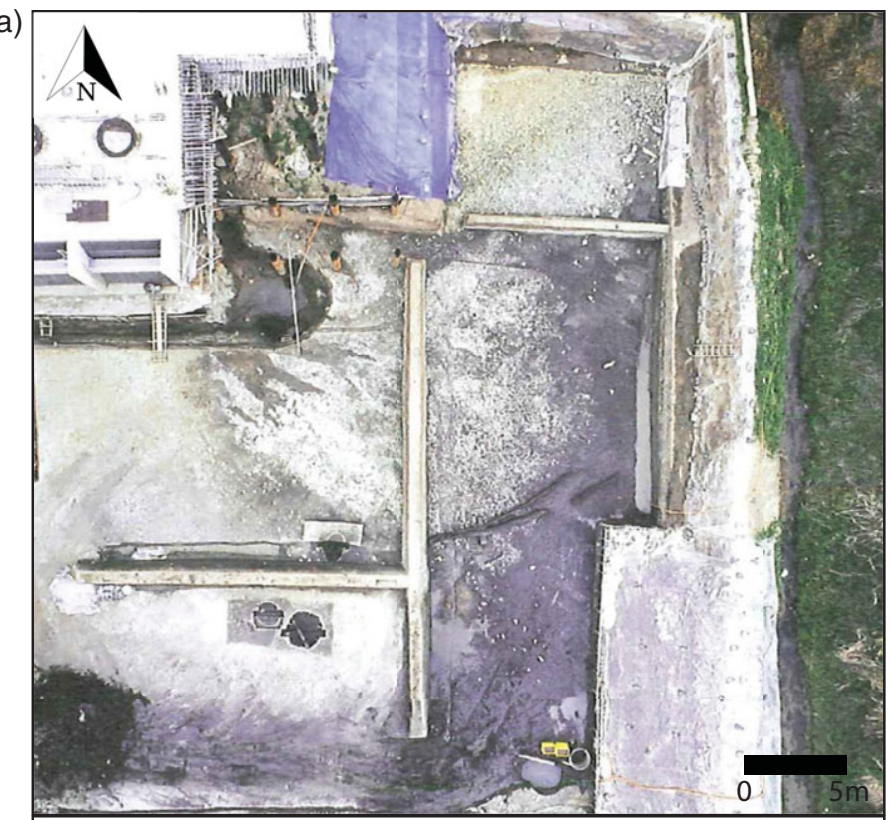

(b)

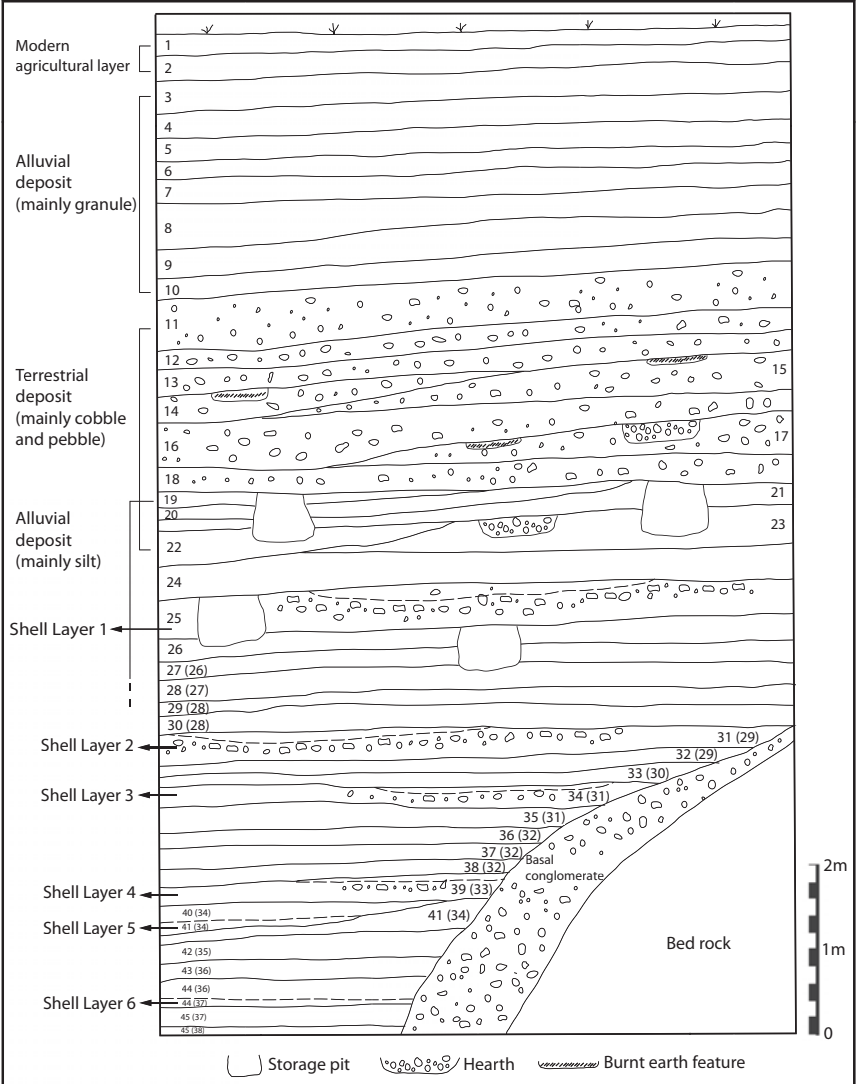

Figure 3 (a) An aerial view of the Bibongri site, showing Shell Layer 1's surface, and (b) a schematic stratigraphic profile (Gimhae National Museum 2008: 14, 193). Stratigraphic layer numbers outside the brackets are copied from the Gimhae National Museum (2008), and numbers inside the brackets are copied from the Gimhae National Museum (2012). 
wetland along with sea-level regression and inundation from the Cheongdo-cheon River. As a result, organic materials were well preserved in multiple layers of silty mud, shell, and alluvial sediments.

Bibongri's high pH level of six shell layers preserved faunal remains in excellent condition, including at least 35 vertebrate and molluscan taxa. Two common species of mollusks are blood cockle (Tegillarca granosa) and pacific oyster (Magallana gigas) (Kaneko 2008; Hwang et al. 2013). Dybowski's sika deer (Cervus nippon hortulorum) and Korean wild boar (Sus scrofa coreanus) are the most common mammalian taxa, similar to other Neolithic shell midden sites in Korea (Lee 2017). Other mammals, fish, and birds were also identified, including dog (Canis lupus familiaris), brown bear (Ursus arctos), raccoon dog (Nyctereutes procyonoides), Mongolian wolf (Canis lupus chanco), Siberian tiger (Panthera tigris tigris), wild water buffalo (Bubalus arnee), Korean ring-necked pheasant (Phasianus colchicus karpowi), duck (Anatidae sp.), redlip mullet (Planiliza haematocheilus), and spotted sea bass (Lateolabrax maculatus) (Kaneko 2008). Artifacts made of organic materials are also preserved intact, including pine dugout canoe and a paddle, basketry, and wooden and bone tools (Gimhae National Museum 2008, 2012).

An earlier study shows domesticated millets became dietary sources by the Middle Neolithic period (ca. 5500-5000 cal BP) (Crawford and Lee 2003). More recent studies based on charred remains and grain impressions on pottery confirm the presence of both foxtail and broomcorn millets in the Early Neolithic context at Tongsamdong (Obata 2013) and Bibongri (Lee et al. 2019; Kwak et al. 2020). Both charred remains and Early Neolithic pottery with millet impressions from Shell Layer 1 at Bibongri push the introduction of millet to the Early Neolithic period (7700-5500 cal BP) (Lee et al. 2019; Kwak et al. 2020). Floated sediments also yielded diverse edible or medicinal plant taxa, including acorn (Quercus cf. serrata, Q. cf. glauca), wild walnut (Juglans sp.), apricot (Prunus armeniaca or P. mandshurica), wild cherry (P. tomentosa), wild grape (Vitis sp.), spicewood (Lindera sp.), hop (Humulus sp.), dogwood (Cornus sp.), and aster (Asteraceae) (Lee 2008, 2017). Overall, the periods when these shell layers accumulated represent a warmer span with seasonally abundant resources (Gimhae National Museum 2008).

Shell Layer 1 is the most thoroughly analyzed stratum at Bibongri since it is the thickest cultural layer and filled with artifacts and organic remains (Figure 3). Shell Layer 1 yielded ten ${ }^{14} \mathrm{C}$ dates on charcoal, bone, and shells published in Gimhae National Museum (2008, 2012), and we added one more ${ }^{14} \mathrm{C}$ date on shell (D-AMS-039265) (Table 3).

\section{RESULTS AND DISCUSSION}

Our two new $\Delta \mathrm{R}$ values are considerably different from those reported by Kong and Lee (2005). However, they are generally within the ranges reported in the coastal regions of East Asia (Tables 1 and 2). Moderate variations in the $\Delta \mathrm{R}$ values in close proximity are not uncommon (Yoshida et al. 2010; Panich et al. 2018). Several factors may have caused this difference, including handling error during the pre-laboratory and laboratory processes (Kim et al. 2016), an inherent variability in the measurement condition of each sample (Scott et al. 2007), and a possibility of exposure to the freshwater runoff depending on the geomorphology of the sample collection location (Ascough et al. 2005).

$\Delta \mathrm{R}$ values of ours and Kong and Lee's (2005) are applied to calculate the weighted mean $\Delta \mathrm{R}$. We report two weighted mean $\Delta \mathrm{R}$ values of $-83 \pm 16$ and $-134 \pm 100$ (Table 3 ). The former is 
Table $3{ }^{14} \mathrm{C}$ dates from Shell Layer 1 at the Bibongri site.

\begin{tabular}{|c|c|c|c|c|c|c|c|}
\hline Lab code & Material & Species & $\begin{array}{c}\delta^{13} \mathrm{C} \\
(\%, \mathrm{VPDB})^{*}\end{array}$ & $\begin{array}{c}{ }^{14} \mathrm{C} \mathrm{BP} \\
\text { (conventional) }\end{array}$ & $\begin{array}{l}\text { Weighted } \\
\text { mean } \Delta R\end{array}$ & cal BP $(1 \sigma)^{* * * *}$ & cal BP $(2 \sigma)^{* * * *}$ \\
\hline SNU05-343 & Charcoal & - & $-27.36^{*}$ & $5330 \pm 40$ & N/A & $\begin{array}{l}6191-6168(11.3 \%) \\
6152-6111(19.9 \%) \\
6082-6007\left(37.2^{\circ} \%\right)\end{array}$ & $\begin{array}{c}6272-6241(6.4 \%) \\
6209-5996(89.0 \%)\end{array}$ \\
\hline SNU10-1098 & Charcoal & - & $-23.39 *$ & $5530 \pm 50$ & N/A & $\begin{array}{l}6393-6368(20.2 \%) \\
6351-6288(48.1 \%)\end{array}$ & $\begin{array}{c}6438-6425(1.4 \%) \\
6407-6272(88.7 \%) \\
6240-6210(5.4 \%)\end{array}$ \\
\hline PLD-19846 & Bone & $\begin{array}{l}\text { Cervus nippon } \\
\text { hortulorum }\end{array}$ & $-23.03^{*}$ & $4935 \pm 25$ & N/A & $\begin{array}{l}5702-5698(2.8 \%) \\
5660-5599(65.4 \%)\end{array}$ & $5720-5596(95.4 \%)$ \\
\hline PLD-19844 & Bone & $\begin{array}{l}\text { Cervus nippon } \\
\text { hortulorum }\end{array}$ & $-22.84^{*}$ & $4940 \pm 20$ & N/A & $\begin{array}{l}5705-5695(6.1 \%) \\
5660-5601(62.1 \%)\end{array}$ & $5718-5598(95.4 \%)$ \\
\hline SNU06-A001 & Shell & $\begin{array}{r}\text { Tegillarca } \\
\text { granosa }\end{array}$ & $-15.21^{*}$ & $4550 \pm 120$ & $\begin{array}{c}-83 \pm 16^{* *} \\
-134 \pm 100^{* * *}\end{array}$ & $\begin{array}{c}4831-4499(68.3 \%) \\
4911-4492(66.9 \%) \\
4480-4465(1.4 \%)\end{array}$ & $\begin{array}{c}5013-4312(95.4 \%) \\
5198-5190(0.2 \%) \\
5177-4288(95.1 \%) \\
4283-4277(0.2 \%)\end{array}$ \\
\hline SNU10-A013 & Shell & $\begin{array}{r}\text { Tegillarca } \\
\text { granosa }\end{array}$ & $-4.26^{*}$ & $5100 \pm 50$ & $\begin{array}{c}-83 \pm 16^{* *} \\
-134 \pm 100^{* * *}\end{array}$ & $\begin{array}{l}5450-5275(68.2 \%) \\
5555-5280(68.2 \%)\end{array}$ & $\begin{array}{l}5551-5159(95.4 \%) \\
5670-5065(95.4 \%)\end{array}$ \\
\hline Beta-219091 & Shell & $\begin{array}{c}\text { Tegillarca } \\
\text { granosa }\end{array}$ & $-8.3^{*}$ & $5230 \pm 40$ & $\begin{array}{c}-83 \pm 16^{* *} \\
-134 \pm 100^{* * *}\end{array}$ & $\begin{array}{l}5579-5415\left(68.2^{\%} \%\right) \\
5685-5408\left(68.2^{\circ} \%\right)\end{array}$ & $\begin{array}{l}5636-5313(95.4 \%) \\
5833-5281(95.4 \%)\end{array}$ \\
\hline D-AMS-039265 & Shell & $\begin{array}{l}\text { Magallana } \\
\text { gigas }\end{array}$ & $1.4^{*}$ & $5727 \pm 28$ & $\begin{array}{c}-83 \pm 16^{* *} \\
-134 \pm 100^{* * *}\end{array}$ & $\begin{array}{l}6106-5937(68.2 \%) \\
6201-5941(68.2 \%)\end{array}$ & $\begin{array}{l}6190-5880(95.4 \%) \\
6327-5801(95.4 \%)\end{array}$ \\
\hline
\end{tabular}

\footnotetext{
${ }^{*}$ The $\delta^{13} \mathrm{C}$ values in this table were calculated using accelerator mass spectrometry (AMS), not isotope ratio mass spectrometry (IRMS).

$* *$ Based on two $\Delta \mathrm{R}$ values derived from one pre-bomb shell sample in this study.

***Based on four $\Delta \mathrm{R}$ values derived from one pre-bomb shell sample in this study and two pre-bomb shell samples from Kong and Lee (2005).

****This study used OxCal 4.3.2 for ${ }^{14} \mathrm{C}$ calibration (Bronk Ramsey 2009, 2017; Bronk Ramsey and Lee 2013). Charcoal and animal bone samples were calibrated using the IntCal20 atmospheric curve, and shell samples were calibrated using the Marine20 marine curve (Heaton et al. 2020; Reimer et al. 2020). Lab codes are listed in the at the Radiocarbon journal website (Radiocarbon 2021).
} 
based on only the two values from our specimen, while the latter combines ours and Kong and Lee's (2005) (Table 1). A larger variation of $\Delta \mathrm{R}$ between ours and Kong and Lee's (2005) contributes to a greater error range in the weighted mean $\Delta \mathrm{R}$ of the latter.

Although Shell Layer 1 revealed the Yunggimun (appliqué) pottery, a typical style of the Initial Neolithic period (8000-7000 cal BP), a majority of pottery found are typical Early Neolithic wares with impressed, punctated, and incised decorations. Based on these pottery types and ${ }^{14} \mathrm{C}$ dates on charcoal fragments (Table 3, Figure 4C), Shell Layer 1 was regarded as the Early Neolithic period (7000-5500 cal BP) (Gimhae National Museum 2008, 2012). As Early Neolithic type vessels were in use for over 1500 years, the pottery typology itself cannot answer specific diachronic questions, including how long inhabitants used the area and when it happened within an over 1,500 year span. We can address the occupational span of Shell Layer 1 by comparing $\Delta \mathrm{R}$ adjusted dates on shells (Figure 4A, 4B) with calibrated dates on charcoal and animal bones (Figure 4C).

The stable isotopic analysis on bones from Shell Layer 1, which were also dated, does not raise a concern of sample contamination, collagen degradation, and carbon-exchange issues. The atomic carbon to nitrogen ratios measured from the bone collagens are 3.1 to 3.3 (Kim 2012). As the ratios of modern animals and humans range 2.9 to 3.6, if an archaeological sample falls within this range, that sample is regarded as reliable (DeNiro 1985). Four bones' collagen yields are around 13.2 weight percent collagen and are within the reliable range of 1.0 to 20.0 (van Klinken 1999).

We calibrated dates on archaeological shells with the two weighted mean $\Delta \mathrm{R}$ values, one based on our samples only, $-83 \pm 16$ (Figure $4 \mathrm{~A}$ ) and the other that combined ours and Kong and Lee's (2005), $-134 \pm 100$ (Figure 4B). Regardless to which of the two weighted mean $\Delta \mathrm{R}$ values are used, charcoal and animal bone dates are several hundred years older than two shell dates (SNU10-A013, Beta-219091). The other shell date, D-AMS-039265, is roughly contemporaneous to charcoal and animal bone dates (Figure 4, Table 3). The shell date, SNU06-A001, is much younger than all other dates found in the same layer. Also, it has the least precision (i.e., large uncertainty), indicating the possibility that the sample was contaminated during the laboratory procedure or relocated from the layer above. Calibrated date ranges of archaeological shells increase by 100-200 years if we apply the combined weighted mean $\Delta \mathrm{R}$ that includes values published by Kong and Lee (2005) (Figure 4B).

The potential impact of the old-wood effect should be examined (Schiffer 1986; Nolan 2012). Arboreal taxa identified at Bibongri through wood charcoal analysis include sawtooth oak (Quercus acutissima Carruth.), Korean red pine (Pinus densiflora), mulberry (Morus sp.), chestnut (Castanea sp.), and maple (Acer sp.) (Lee and Oh 2008). Pine and oak can live up to 1000 years under the right conditions. A previous study, however, suggests that the old-wood effect did not produce any consistent difference between the dates on annual seeds and wood charcoal from several Neolithic and Bronze period sites in Korea (ca. 8000-3500 BP) (Hwang et al. 2016). Contrary to the expectation of the old-wood effect, seeds appeared to be about 35 years older than charcoal on average. A contrasting pattern has been observed in historical sites (ca. 1700-1100 cal BP), where the dates on charcoal were older than those on seeds. In historical periods, thicker and older lumbers were likely used to build long-term houses, contributing to the old-wood effect (Hwang et al. 2016). 
(a)
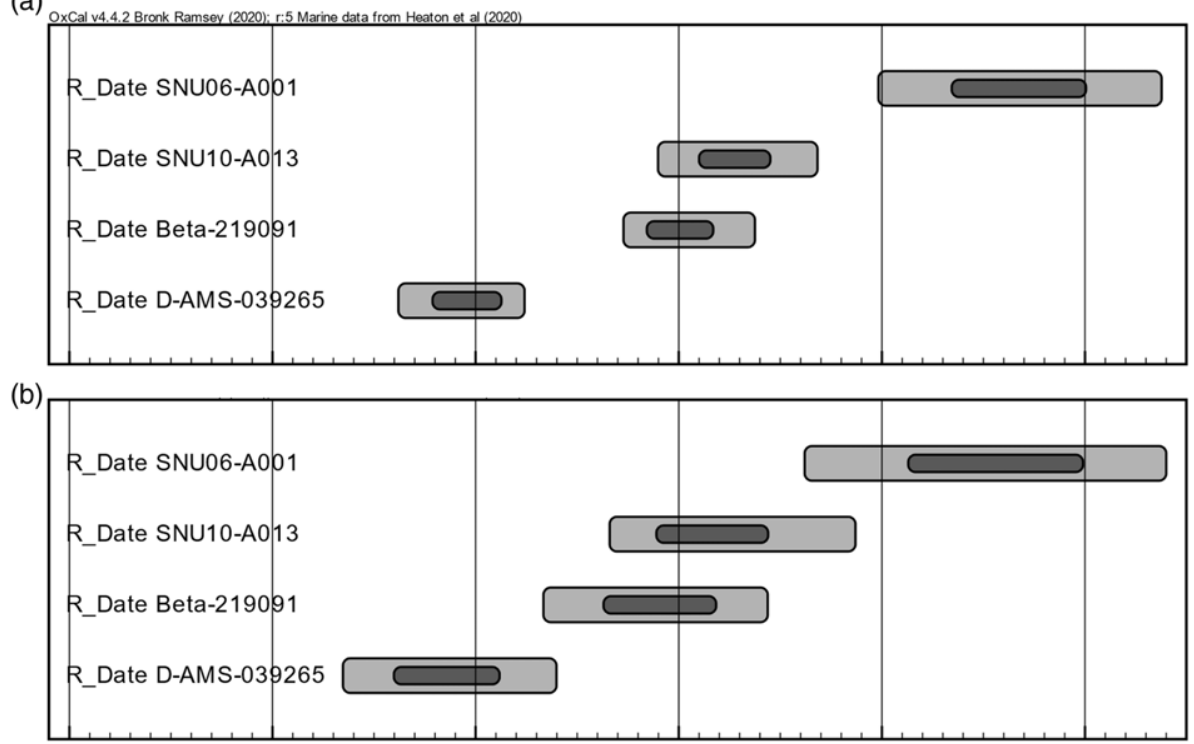

(c)

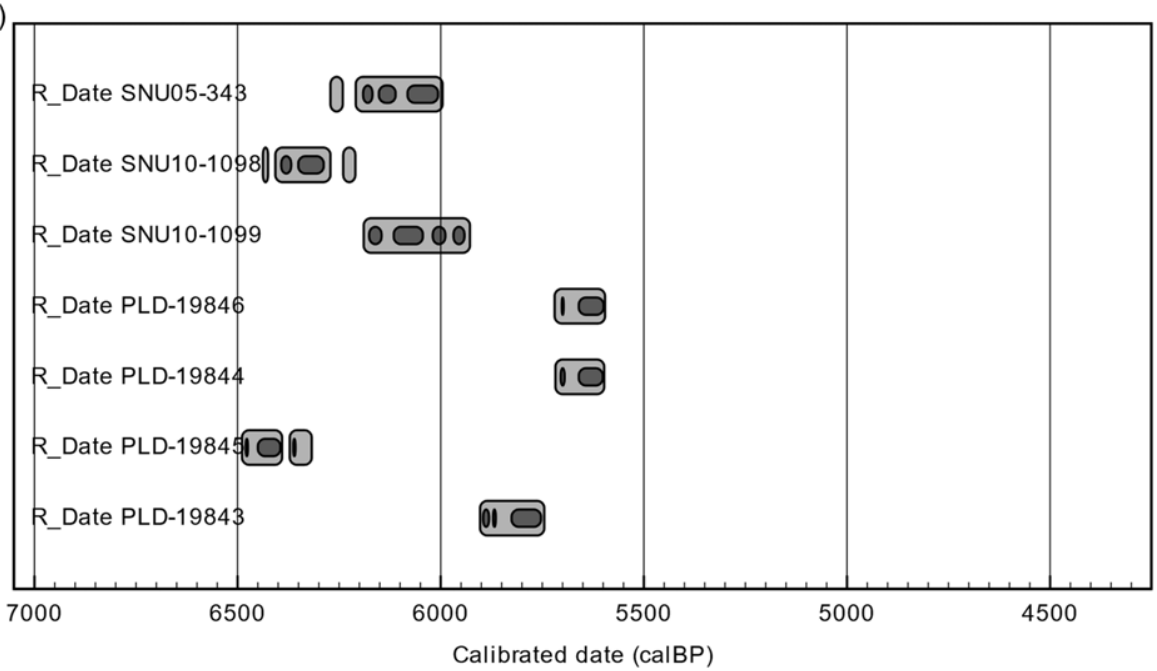

$68.2 \%$ probability range

$95.4 \%$ probability range

Figure 4 Comparison of $11{ }^{14} \mathrm{C}$ dates from Shell Layer 1 at the Bibongri site: (a) Dates on shells calibrated by the weighted mean $\Delta \mathrm{R}$ value of $-83 \pm 16$ derived from the pre-bomb shell in this study (see Table 2). (b) Dates on shells calibrated by the weighted mean $\Delta \mathrm{R}$ value of $-134 \pm 100$ derived from the pre-bomb shell in this study and Kong and Lee (2005). (c) Calibrated dates on charcoal and terrestrial animal bones. Calibration performed with OxCal 4.3.2 (Bronk Ramsey 2009, 2017; Bronk Ramsey and Lee 2013), based on IntCal20 atmospheric curve and Marine20 marine curve (Heaton et al. 2020; Reimer et al. 2020).

Schiffer (1986) first warned the old-wood effect by examining the dates from the southwest United States. However, Cook and Comstock (2014) identified a much lesser degree of old-wood effects from the Fort Ancient sites (2200-1600 BP) across southwestern Ohio and southeastern Indiana. They found that the decomposition rates of wood are generally very high in the temperate climate there. That is, the availability of old wood is much lower in 
the temperate climate than in the arid zone. Southeastern Korea is in a temperate climate zone with distinct seasonal cycles of hot humid summer with monsoon, followed by dry cold winter. This climate condition may reduce the old-wood effect, similar to what Cook and Comstock (2014) observed in the United States.

Diatom analysis also indicates that Bibongri was influenced by saline seawater (Hwang 2008). Salty water is known to promote the decaying of wood (Shupe et al. 2008). Wood probably had a very low chance to survive for a substantive period of time in a seasonally wet condition and a saline water influx at Bibongri. The old-wood effect is less likely to have occurred at Bibongri unless wood materials have a highly durable composition like those in the early historical period in Korea. Accordingly, we can conclude that the age difference between charcoal and shells unlikely resulted from an old-wood effect. The earliest date on charcoal (SNU10-1098) and the latest date on shell (SNU10-A013) are several hundred years apart at the 2 sigma level. The range suggests that Shell Layer 1 was accumulated over an extended period of time between 6400 and 5000 cal BP.

Our data show that the use of marine reservoir correction values $(\Delta \mathrm{R})$ on marine shells can improve our understanding of the site chronology. A chronology based heavily on a pottery typology can only suggest that an entire stratum over $1 \mathrm{~m}$ thick belongs to a singular "Early Neolithic" period. The stratigraphic sequence and the site's specific duration of use cannot be understood exclusively based on pottery typology or uncalibrated radiocarbon years of marine and aquatic species. With an accurate calibration of marine dates and charcoal, we are able to understand the depth of time span through which multiple generations inhabited the area.

Bibongri is a multi-generational site used by those who shared the Early Neolithic pottery tradition over hundreds of years. Early Neolithic people likely dwelled at or revisited Bibongri to take advantage of its broad-spectrum resources over generations. Archaeobotanical and zooarchaeological studies conducted at the site reflect diverse seasonal marine and terrestrial resources throughout the year (Kaneko 2008; Kwak et al. 2020). Bibongri presented an affluent environment during the period where these shell middens were used. Numerous artifacts that represent diverse activities were recovered from Shell Layer 1, including digging tools, stone knives, axes, adzes, whetstones, grinding stones, spears, fishing hooks, and net sinkers (Gimhae National Museum 2008, 2012). This diverse combination of tools and dwelling structures represent at least multi-seasonal settlements at Bibongri. Diverse seasonal resources, which are reflected in plant and animal remains, were attractive to Bibongri people; they were able to sustain themselves through fishing-shellfishing, hunting, wild plant harvesting, and millet cultivation during the Early Neolithic period (Kwak et al. 2020). A long tradition of such broad-spectrum resource use probably made Bibongri a vital cultural niche over several hundred years, similar to the findings on the east coast of Korea (Lee et al. 2019).

\section{CONCLUSION AND FUTURE DIRECTIONS}

We added two additional $\Delta \mathrm{R}$ values to the Pacific database by dating the pre-bomb (pre-1950) blue mussel shell (Mytilus edulis) from the southern coastal region of Korea. As a pioneering case study, we calibrated archaeological shell samples from Shell Layer 1 of the Bibongri Neolithic shell midden, where dates on charcoal are also available. By comparing the dates on charcoal samples with the $\Delta \mathrm{R}$ calibrated shell dates, we demonstrate that Shell Layer 1 
represents long-term human activities over several hundred years, and thus improves our understanding of the site chronology. Our Bibongri case study demonstrates that properly calibrated shell dates can play a key role in improving the chronological understanding of Neolithic shell midden in Korea. Moving forward, we will investigate the variation of $\Delta R$ across the Korean Peninsula and its contributing causes by reporting additional $\Delta \mathrm{R}$ using pre-bomb shell samples and pairing them with the dates on terrestrial samples to build a fine-grained chronology of the Neolithic Period.

\section{ACKNOWLEDGMENTS}

This work was supported by the Laboratory Program for Korean Studies through the Ministry of Education of the Republic of Korea and Korean Studies Promotion Serive of the Academy of Korean Studies (AKS-2015-Lab-2250001). A special thanks to Hae-jin Chang at the Fisheries Science Museum (a branch of the National Fisheries Research and Development Institute) and Jung-Jin Kim at the Coastal Water Fisheries Resources Research Division of the National Institute of Fisheries Science for providing us with the pre-bomb bivalve specimens. We appreciate Hakjong Im (Gimhae National Museum) and Junggeun Lee (Jinju National Museum) for providing us with flotation samples and photos of the Bibongri site. Our gratitude goes out to Sangtaek Lim (Pusan National University) who helped us to receive modern shell specimens. We are grateful to Amira Ainis (University of Oregon) for training us in sample processing, and to Ilya Bindeman and Jim Palandri (University of Oregon) in isotopic analysis. We appreciate Geesoo Kong (Korea Institute of Geoscience and Mineral Resources) for guidance in accessing pre-bomb shell samples. We are also thankful to Scott Fitzpatrick (University of Oregon) for allowing us to prepare our samples in the Coastal and Island Archaeology Laboratory.

\section{SUPPLEMENTARY MATERIAL}

To view supplementary material for this article, please visit https://doi.org/10.1017/RDC. 2021.45

\section{REFERENCES}

Ahn S-M, Kim JS, Hwang JH. 2015. Sedentism, settlements, and radiocarbon dates of Neolithic Korea. Asian Perspectives 54(1):113-143. doi: 10.1353/asi.2015.0005.

Al-Dabbas MAM, Hubbard FH, McManus J. 1984. The shell of Mytilus as an indicator of zonal variations of water quality within an estuary. Estuarine, Coastal and Shelf Science 18(3): 263-270. doi: 10.1016/0272-7714(84)90071-4.

Anderson DG, Goodyear AC, Kennett J, West A. 2011. Multiple lines of evidence for possible human population decline/settlement reorganization during the early Younger Dryas. Quaternary International 242(2):570-583. doi: 10.1016/j.quaint.2011.04.020.

Ascough P, Cook G, Dugmore A. 2005. Methodological approaches to determining the marine radiocarbon reservoir effect. Progress in Physical Geography: Earth and Environment 29(4):532-547. doi: 10.1191\%2F0309133305pp 461 ra.
Bae K, Bae CJ, Kim J. 2013. Reconstructing human subsistence strategies during the Korean Neolithic: Contributions from zooarchaeology, geosciences, and radiocarbon dating. Radiocarbon 55(3):1350-1357. doi: 10.1017/S0033822200048268.

Bevington PR. 1969. Data reduction and error analytics for the physical sciences. New York: McGraw-Hill. 336 p.

Bronk Ramsey C. 2009. Bayesian analysis of radiocarbon dates. Radiocarbon 51(1):337-360. doi: $10.1017 /$ S0033822200033865.

Bronk Ramsey C. 2017. OxCal Program v. 4.3.2. The Oxford Radiocarbon Accelerator Unit, University of Oxford. URL: http://c14.arch.ox.ac.uk/oxcal help/hlp_contents.html. Accessed March 1, 2021.

Bronk Ramsey C, Lee S. 2013. Recent and planned developments of the program Oxcal Radiocarbon 55(2-3):720-30. doi: 10.1017/S003382220 0057878 .

Butler PG, Scourse JD, Richardson CA, Wanamaker Jr. AD, Bryant CL, Bennell JD. 
2009. Continuous marine radiocarbon reservoir calibration and the ${ }^{13} \mathrm{C}$ Suess effect in the Irish Sea: Results from the first multi-centennial shell-based marine master chronology. Earth and Planetary Science Letters 279(3-4):230-241. doi: 10.1016/j.epsl.2008.12.043.

Cook GT, Ascough PL, Bonsall C, Hamilton WD, Russell N, Sayle KL, Scott EM, Bownes JM. 2015. Best practice methodology for ${ }^{14} \mathrm{C}$ calibration of marine and mixed terrestrial/ marine samples. Quaternary Geochronology 27:164-171. doi: 10.1016/j.quageo.2015.02.024.

Cook RA, Comstock AR. 2014. Evaluating the old wood problem in a temperate climate: A Fort Ancient case study. American Antiquity 79(4):763-775. doi: 10.7183/0002-7316.79.4.763.

Crawford GW, Lee G-A. 2003. Agricultural origins in the Korean Peninsula. Antiquity 77(295):87-95. doi: 10.1017/S0003598X00061378.

Crema ER, Habu J, Kobayashi K, Madella M. 2016. Summed probability distribution of ${ }^{14} \mathrm{C}$ dates suggests regional divergences in the population dynamics of the Jomon period in eastern Japan. PLoS ONE 11(4):e0154809. doi: 10.1371/journal. pone.0154809.

DeNiro MJ. 1985. Postmortem preservation and alteration of in vivo bone collagen isotope ratios in relation to palaeodietary reconstruction. Nature 317:806-809. doi: 10.1038/317806a0.

Gimhae National Museum. 2008. Bibong-ri Site, Changnyeong: The Neolithic low-lying wetland site. Report on the Research of Antiquities of the Gimhae National Museum, Vol. 6. Gimhae: Gimhae National Museum Press. 457 p. In Korean with English abstract.

Gimhae National Museum. 2012. Bibong-ri Site, Changnyeong: The Neolithic low-lying shell midden site. Report on the Research of Antiquities of the Gimhae National Museum, Vol. 9. Gimhae: Gimhae National Museum Press. 336 p. In Korean.

Ha IS. 2010. The state and commission of shellmidden research. In: Korean Cultural Properties Investigation and Research Institute Association, editor. Shell midden sites of Korea. Daejeon: Korean Cultural Properties Investigation and Research Institute Association. p. 1106-1149. In Korean.

Heaton TJ, Köhler P, Butzin M, Bard E, Reimer RW, Austin WEN, Bronk Ramsey C, Grootes PM, Hughen KA, Kromer B, Reimer P, Adkins J, Burke A, Cook MS, Olsen J, Skinner LC. 2020. Marine20 - the marine radiocarbon age calibration curve (0-55,000 cal BP). Radiocarbon 62(4):779-820. doi: 10.1017/RDC.2020.68.

Hirabayashi S, Yokoyama Y, Suzuki A, Miyairi Y, Aze T. 2017. Short-term fluctuations in regional radiocarbon reservoir age recorded in coral skeletons from the Ryukyu Islands in the northwestern Pacific. Journal of Quaternary Science 32(1):1-6. doi: 10.1002/jqs.2923.
Hong SY. 2006. Marine invertebrates in Korean coasts. Seoul: Academy Publishing Company, Inc. 479 p. In Korean.

Hughen KA, Baillie MGL, Bard E, Warren Beck J, Bertrand CJH, Blackwell PG, Buck CE, Burr GS, Cutler KB, Damon PE, Edwards RL, Fairbanks RG, Friedrich M, Guilderson TP, Kromer B, McCormac G, Manning S, Bronk Ramsey C, Reimer PJ, Reimer RW, Remmele S, Southon JR, Stuiver M, Talamo S, Taylor FW, Van der Plicht J, Weyhenmeyer CE. 2004. Marine04 marine radiocarbon age calibration, 0-26 cal kyr BP. Radiocarbon 46(3): 1059-1086. doi: 10.1017/S0033822200033002.

Hwang JH, Kim JS, Lee YS, Lee JY, Song AR, Kim J-K, Park JY, Yang JW, Yang HM, Kang SH, Oh YJ, Ahn S-M, Choi JT, Seong CT, Wright DK, Choi SH, Hyun CH. 2016. Radiocarbon dating and old wood effect: An experiment and archaeological assessment. Journal of the Korean Ancient Historical Society 92:117-149. In Korean with English abstract

Hwang SI. 2008. Analysis of geography and diatoms in Changnyeong Bibong-ri Neolithic Site area. In: Gimhae National Museum, editor. Bibong-ri Site, Changnyeong: The Neolithic low-lying wetland site. Report on the Research of Antiquities of the Gimhae National Museum, Vol. 6. Gimhae: Gimhae National Museum Press. p. 405-438. In Korean.

Hwang SI. 2012. Diatom analysis in Changnyeong Bibong-ri Neolithic Site area. In: Gimhae National Museum, editor. Bibong-ri Site, Changnyeong: The Neolithic low-lying shell midden site. Report on the Research of Antiquities of the Gimhae National Museum, Vol. 9. Gimhae: Gimhae National Museum Press. p. 313-330. In Korean.

Hwang SI, Kim JY, Yoon SO. 2013. Sea Level Change during the Middle Holocene at Bibongri, Changnyeong-gun, Gyeongsangnam-do, South Korea. Journal of the Korean Geographical Society 48(6):837-855. In Korean with English abstract.

Jull AJT, Burr GS, Hodgins GWL. 2013. Radiocarbon dating, reservoir effects, and calibration. Quaternary International 299:64-71.

Jull AJT, Kuzmin YV, Lutaenko KA, Orlova LA, Popov AN, Rakov VA, Sulerzhitsky LD. 1994. Composition, age and habitat of the Boisman 2 Neolithic site in the Maritime territory. Doklady Biological Sciences 339:620-623.

Kaneko H. 2008. Animal remains from Changnyeong Bibong-ri Site. In: Gimhae National Museum, editor. Bibong-ri Site, Changnyeong: The Neolithic low-lying wetland site. Report on the Research of Antiquities of the Gimhae National Museum, Vol. 6. Gimhae: Gimhae National Museum Press. p. 305-390. In Korean and Japanese.

Kim HS. 2012. Diet and chronology of the dog remains from Bibong-ri Site. In: Gimhae 
National Museum, editor. Bibong-ri Site, Changnyeong: The Neolithic low-lying shell midden site. Report on the Research of Antiquities of the Gimhae National Museum, Vol. 9. Gimhae: Gimhae National Museum Press. p. 293-297. In Korean.

Kim JS, Wright DK, Lee YS, Lee JY, Choi SH, Kim JK, Ahn S-M, Choi JT, Seong CT, Hyun CH, Hwang JH, Yang HM, Yang JW. 2016. AMS dates from two archaeological sites of Korea: Blind tests. Radiocarbon 58(1):115-130. doi: 10 . 1017/RDC.2015.10.

Kong GS, Lee CW. 2005. Marine reservoir corrections $(\Delta R)$ for southern coastal waters of Korea. The Sea: Journal of the Korean Society of Oceanography 10(2):124-128. In Korean with English abstract.

Kuzmin YV, Burr GS, Jull AJT. 2001. Radiocarbon Reservoir Correction Ages in the Peter the Great Gulf, Sea of Japan, and Eastern Coast of the Kunashir, Southern Kuriles (Northwestern Pacific). Radiocarbon 43(2A):477-481. doi: 10. 1017/S0033822200038364.

Kuzmin YV, Orlova LA, Sulerzhitsky LD, Jull AJT. 1994. Radiocarbon dating of the Stone and Bronze Age sites in Primorye (Russian Far East). Radiocarbon 36(3):359-366. doi: 10.1017/S0033 822200014533.

Kuzmin YV, Richards MP, Yoneda M. 2002. Palaeodietary patterning and radiocarbon dating of Neolithic populations in the Primorye Province, Russian Far East. Ancient Biomolecules 4(2):53-58. doi: 10.1080/135861202100 0010695.

Kwak SK, Obata H, Lee G-A. 2020. Broad-spectrum foodways in southern coastal Korea in the Holocene: Isotopic and archaeobotanical signatures in Neolithic shell middens. The Journal of Island and Coastal Archaeology. doi: 10.1080/15564894.2020.1776427.

Lee G-A. 2008. A report on the plant remains from the Bibong-ri Site. In: Gimhae National Museum, editor. Bibong-ri Site, Changnyeong: The Neolithic low-lying wetland site. Report on the Research of Antiquities of the Gimhae National Museum, Vol. 6. Gimhae: Gimhae National Museum Press. p. 391-398. In Korean.

Lee G-A. 2017. The Chulmun period of Korea: current findings and discourse on the Korean Neolithic culture. In: Habu J, Lape P, Olsen J, editors. Handbook of East and Southeast Asian Archaeology. New York, NY: Springer International Publishing. p. 451-482.

Lee G-A, Cho MS, Obata H. 2019. Coastal farmers during the early and middle Holocene: Archaeobotanical and grain impression studies on the east coast Korea. Quaternary International 529:57-74. doi: 10.1016/j.quaint.2019.10.013.

Lee HS, Oh SJ. 2008. Identification of wood materials from Changnyeong Bibong-ri Site. In: Gimhae National Museum, editor. Bibong-ri Site,
Changnyeong: The Neolithic low-lying wetland site. Report on the Research of Antiquities of the Gimhae National Museum, Vol. 6. Gimhae: Gimhae National Museum Press. p. 399-404. In Korean.

Lee TS, Mok JS, Son KT, Oh EK, Kim PH, Lee, GJ, Lee HJ, Kim JH. 2006. Paralytic shellfish poisoning in mussel from coastal area of Korea. Busan: National Institute of Fisheries Science. 109 p. In Korean.

Levin I, Kromer B, Schoch-Fischer H, Bruns M, Münnich M, Berdau D, Vogel JC, Münnich KO. 1985. 25 years of tropospheric ${ }^{14} \mathrm{C}$ observations in central Europe. Radiocarbon 27(1):1-19. doi: 10. 1017/S0033822200006895.

Nakanishi T, Takemura K, Matsuyama H, Shimoyama S, Hong W, Okuno M. 2017. Activity of the Funai Fault and radiocarbon age offsets of shell and plant pairs from the latest Pleistocene to Holocene sediments beneath the Oita Plain, western Japan. Radiocarbon 59(6):1737-1748. doi: 10.1017/RDC.2017.119.

Napolitano MF, Fitzpatrick SM, Clark G, Stone JH. 2019. New Investigations of Early Prehistoric Settlement on Yap, Western Caroline Islands. The Journal of Island and Coastal Archaeology 14(1):101-117. doi: 10.1080/15564894.2017.1335661.

Nolan KC. 2012. Temporal Hygiene: Problems in cultural chronology of the late prehistoric period of the middle Ohio River Valley. Southeastern Archaeology 31(2):185-206. doi: 10.1179/sea.2012.31.2.004.

Nydal R. 1968. Further investigation on the transfer of radiocarbon in nature. Journal of Geophysical Research 73(12):3617-3635. doi: 10.1029/JB073i $012 \mathrm{p} 03617$.

Obata H. 2013. Descriptions on the diagnostic characteristics for identification of millet impressions from Dongsamdong Shell Midden and Bibongri Site. Journal of Korean Neolithic Society 25:105-155. In Korean with English abstract.

Oh YJ, Conte M, Kang SH, Kim JS, Hwang JH. 2017. Population fluctuation and the adoption of food production in prehistoric Korea: using radiocarbon dates as a proxy for population change. Radiocarbon 59(6):1761-70. doi: 10.1017/ RDC.2017.122.

Panich LM, Schneider TD, Engel P. 2018. The marine radiocarbon reservoir effect in Tomales Bay, California. Radiocarbon 60(3):963-974. doi: 10. 1017/RDC.2018.26.

Park JY, Wright DK, Kim JS. 2017. Change in settlement distribution and the emergence of an early state: A spatial analysis of radiocarbon dates from Southwestern Korea. Radiocarbon 59(6):1779-1791. doi: 10.1017/RDC.2017.93.

Phelan MB. 1999. A Delta R correction value for Samoa from known-age marine shells. Radiocarbon 41(1):99-101. doi: 10.1017/S00338 22200019366. 
QUB (Queen's University Belfast). 2021a. Calculate $\triangle \mathrm{R}$. 14CHRONO website. http://calib.org/ deltar/.

QUB (Queen's University Belfast). 2021b. Marine reservoir correction. 14CHRONO website. http://calib.org/marine/AverageDeltaR.html.

Radiocarbon. 2021. List of known radiocarbon laboratories. http://radiocarbon.webhost.uits. arizona.edu/node/11.

Reimer PJ, Austin WEN, Bard E, Bayliss A, Blackwell PG, Bronk Ramsey C, Butzin M, Cheng H, Edwards RL, Friedrich M, Grootes PM, Guilderson TP, Hajdas I, Heaton TJ, Hogg AG, Hughen KA, Kromer B, Manning SW, Muscheler R, Palmer JG, Pearson C, van der Plicht J, Reimer RW, Richards DA, Scott EM, Southon JR, Turney CSM, Wacker L, Adolphi F, Büntgen U, Capano M, Fahrni S, Fogtmann-Schulz A, Friedrich R, Köhler P, Kudsk S, Miyake F, Olsen J, Reinig F, Sakamoto M, Sookdeo A, Talamo S. 2020. The IntCal20 Northern Hemisphere radiocarbon age calibration curve (0-55 cal kBP). Radiocarbon 62(4):725-757. doi: 10.1017/RDC.2020.41.

Reimer PJ, Bard E, Bayliss A, Beck JW, Blackwell PG, Ramsey CB, Buck CE, Cheng H, Edwards RL, Friedrich M, Grootes PM, Guilderson TP, Haflidason H, Hajdas I, Hatté C, Heaton TJ, Hoffmann DL, Hogg AG, Hughen KA, Kaiser KF, Kromer B, Manning SW, Niu M, Reimer RW, Richards DA, Scott EM, Southon JR, Staff RA, Turney CSM, van der Plicht J. 2013. IntCal13 and Marine13 radiocarbon age calibration curves $0-50,000$ years cal BP. Radiocarbon 55(4):1869-1887. doi: 10.2458/azu_ js_rc.55.16947.

Schiffer MB. 1986. Radiocarbon dating and the 'old wood' problem: the case of the Hohokam chronology. Journal of Archaeological Science 13(1):13-30. doi: 10.1016/0305-4403(86)90024-5.

Shupe T, Lebow S, Ring D. 2008. Causes and control of wood decay, degradation and stain. Baton Rouge (LA): Louisiana State University Agriculture Center. Publication 2703.

Scott EM, Gordon CT, Naysmith P. 2007. Error and uncertainty in radiocarbon measurements. Radiocarbon 49(2):427-440. doi: 10.1017/S0033 822200042351 .

Seed R. 1969. The ecology of Mytilus edulis L. (Lamellibranchiata) on exposed rocky shores: 2 . Growth and mortality. Oecologia 3:317-350. doi: 10.1007/BF00390381.

Shishikura M., Echigo T, Kaneda H. 2007. Marine reservoir correction for the Pacific coast of central Japan using ${ }^{14} \mathrm{C}$ ages of marine mollusks uplifted during historical earthquakes. Quaternary Research 67(2):286-291. doi: 10. 1016/j.yqres.2006.09.003.
Smittenberg RH, Hopmans EC, Schouten S, Hayes JM, Eglinton TI, Damsté JSS. 2004. Compound-specific radiocarbon dating of the varved Holocene sedimentary record of Saanich Inlet, Canada. Paleoceanography and Paleoclimatology 19(2):1-16. doi: 10.1029/2003PA00 0927.

Soares AMM, Martins JMM. 2010. Radiocarbon dating of marine samples from Gulf of Cadiz: The reservoir effect. Quaternary International 221(1-2):9-12. doi: 10.1016/j.quaint.2009.10.012.

Southon J, Kashgarian M, Fontugne M, Metivier B, Yim WW-S. 2002. Marine reservoir corrections for the Indian Ocean and Southeast Asia. Radiocarbon 44(1):167-180. doi: 10.1017/S003 3822200064778.

Stuiver M, Reimer PJ, Bard E, Beck JW, Burr GS, Hughen KA, Kromer B, McCormac G, van der Plicht J, Spurk M. 1998. IntCa198 radiocarbon age calibration, 24,000-0 cal BP. Radiocarbon 40(3):1041-1083. doi: 10.1017/S003382220001 9123.

Thiesen BF. 1973. The growth of Mytilus edulis L. (Bivalvia) from Disko and Thule district, Greenland. Ophelia 12(1-2):59-77. doi: 10.1080/ 00785326.1973 .10430120$.

Thornalley DJR, McCave IN, Elderfield H. 2011. Tephra in deglacial ocean sediments south of Iceland: Stratigraphy, geochemistry and oceanic reservoir ages. Journal of Quaternary Science 26(2):190-198. doi: 10.1002/jqs.1442.

Van Klinken GJ. 1999. Bone collagen quality indicators for palaeodietary and radiocarbon measurements. Journal of Archaeological Science 26:687-695. doi: 10.1006/jasc.1998.0385.

Williams JR, Dellapenna TM, Lee GH. 2013. Shifts in depositional environments as a natural response to anthropogenic alterations: Nakdong Estuary, South Korea. Marine Geology 343(C): 47-61. doi: 10.1016/j.margeo.2013.05.010.

Yoneda M, Uno H, Shibata Y, Suzuki R, Kumamoto Y, Yoshida K, Sasaki T, Suzuki A, Kawahata H. 2007. Radiocarbon marine reservoir ages in the western Pacific estimated by pre-bomb molluscan shells. Nuclear Instruments and Methods in Physics Research Section B: Beam Interactions with Materials and Atoms 259(1):432-437. doi: 10.1016/j.nimb. 2007.01.184.

Yoshida K, Tatsuaki H, Kunikita D, Miyazaki Y, Sasaki T, Yoneda M, Matsuzaki H. 2010. Pre-bomb marine reservoir ages in the Western Pacific. Radiocarbon 52(3):1197-1206. doi: 10. 1017/S0033822200046270.

Zoppi U. 2010. Radiocarbon AMS data analysis: from measured isotopic ratios to ${ }^{14} \mathrm{C}$ concentrations. Radiocarbon 52(1):165-170. doi: $10.1017 / \mathrm{S} 0033822200045112$. 